
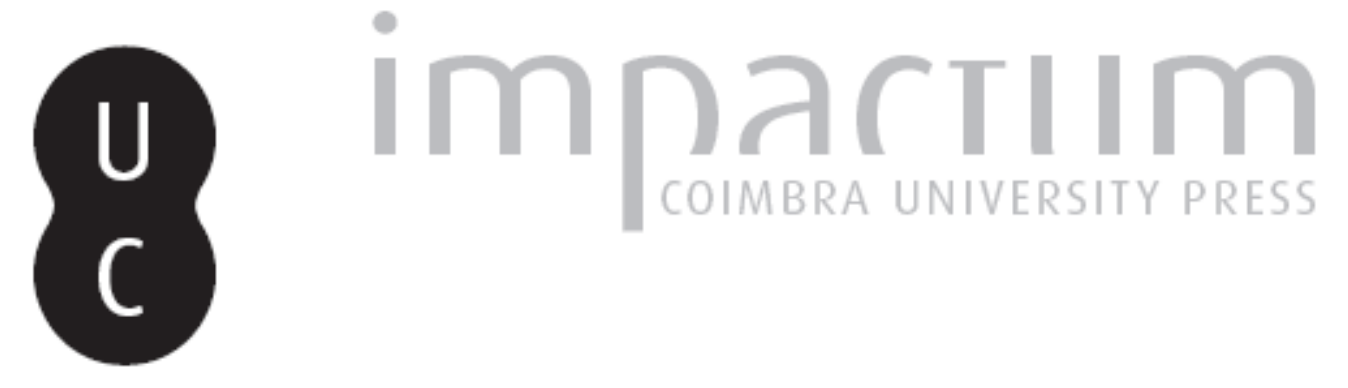

Cataldo e alguns alunos

Autor(es): Ramalho, A. Costa

Publicado por: Associação Portuguesa de Estudos Clássicos; Instituto de Estudos

URL

persistente:

URI:http://hdl.handle.net/10316.2/30474

DOI:

DOI:http://dx.doi.org/10.14195/0872-2110_49_11

Accessed : $\quad$ 26-Apr-2023 14:02:38

A navegação consulta e descarregamento dos títulos inseridos nas Bibliotecas Digitais UC Digitalis, UC Pombalina e UC Impactum, pressupõem a aceitação plena e sem reservas dos Termos e Condições de Uso destas Bibliotecas Digitais, disponíveis em https://digitalis.uc.pt/pt-pt/termos.

Conforme exposto nos referidos Termos e Condições de Uso, o descarregamento de títulos de acesso restrito requer uma licença válida de autorização devendo o utilizador aceder ao(s) documento(s) a partir de um endereço de IP da instituição detentora da supramencionada licença.

Ao utilizador é apenas permitido o descarregamento para uso pessoal, pelo que o emprego do(s) título(s) descarregado(s) para outro fim, designadamente comercial, carece de autorização do respetivo autor ou editor da obra.

Na medida em que todas as obras da UC Digitalis se encontram protegidas pelo Código do Direito de Autor e Direitos Conexos e demais legislação aplicável, toda a cópia, parcial ou total, deste documento, nos casos em que é legalmente admitida, deverá conter ou fazer-se acompanhar por este aviso.

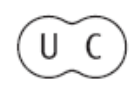




\section{Boletim de}

\section{Estudos Clássicos}

Associação Portuguesa de Estudos Clássicos Instituto de Estudos Clássicos

Coimbra

Junho de 2008 


\title{
Cataldo e Alguns Alunos
}

\author{
Cataldus illustrissimae Marchiae Salutem
}

Credo prius ab hac uita decedam quam Marchionem dominum nostrum cum tota familia in curia regia, aut me istic uobiscum uideam.

Rex per mensem ante discessum in urbem suum, mihi multis praesentibus praecepit ut Antonii leuiri tui filios erudirem, dicens si unquam rem aliquam momenti alicuius commendasset, hanc supra omnes ponerem. Mox quis filiorum Marchionis ingenio excelleret interrogauit. Respondi hac similitudine utens: "Quaelibet arbores quantumuis fructiferae sint, fructus non omnes aequales similesue producunt. Sola pomorum de quibus rogas arbor suos foetus emittit eadem paritate optimos. Solebam quondam Comiti Alcotini palmam constantissime donare. Nunc uero dubito utri dare debeam ipsine Comiti an Sibyllae sorori Lianorae nomine. Nec magnus senex patruelis illis surgit dedecori". Quibus uerbis Antonius tantam animo laetitiam concepit quantam multo ante tempore uix conceperat.

Si cupis scire plura, litterae quas ad tris filios tuos destino poterunt te longe diffusius de multis monere. Vale.

C4 verso (1)

\section{Comentário}

Nesta carta à marquesa de Vila Real, D. Maria Freire, mãe de seus alunos, D. Pedro de Meneses, $2^{\circ}$ conde de Alcoutim, e sua irmã, D. Leonor de Noronha, Cataldo comunica-lhe o interesse do rei D. Manuel pelos progressos nos estudos dos seus filhos.

O humanista informa também a marquesa de que o rei lhe recomendara especialmente a instrução dos filhos de D. António de Noronha, cunhado de D. Maria Freire e conde de Linhares. Destes filhos distingue o pequeno D. Inácio de Noronha, um puer senex, isto é, criança nos anos mas velho na sabedoria. Infelizmente, Cataldo enganou-se com este seu aluno que mais tarde se desmandou nos costumes, sendo obrigado a renunciar ao título nobiliárquico de seu pai. 
Esta carta tem o interesse de nos mostrar as preocupações do rei D. Manuel com a educação dos seus súbditos, interesse que já foi negado por Elisabeth Feist Hirsch na sua biografia de Damião de Góis.

Note-se que, na opinião de Cataldo, a sua aluna D. Leonor de Noronha não era inferior como latinista a seu irmão Pedro. Mais tarde, publicou a Coronica Geral de Marco Antonio Cocio Sabelico des ho começo do mundo ate nosso tempo tresladada de latim em lingoagẽ Portugues por Dona Lianor filha do Marques de Vila Real Dom Fernando, Coimbra, 1550.

A tradução desta carta de Cataldo encontra-se em Cataldo Parísio Sículo. Epístolas, II Parte. Fixação do texto latino, tradução, prefácio e notas de Américo da Costa Ramalho e de Augusta Fernanda Oliveira e Silva, Lisboa, Imprensa Nacional - Casa da Moeda, 2005, p. 171.

A. COSTA RAMALHO 